\title{
歯原性腫瘍の臨床統計的検討：23年間110例について
}

\author{
相馬陽・高木律男・星名秀行 \\ 宮浦靖司・長島克弘・宮本猛
}

\section{Clinicostatistical evaluation of odontogenic tumors: Report of 110 cases during the past 23 years}

\author{
Yoh Sohma $\cdot$ Ritsuo Takagi $\cdot$ Hideyuki Hoshina \\ Yasushi Miyaura $\cdot$ Katsuhiro Nagashima $\cdot$ Takeshi Miyamoto
}

\begin{abstract}
One hundred ten cases of odontogenic tumors histologically diagnosed according to the WHO classification (1992) were clinicostatistically evaluated at our clinic over the 23-year period from 1973 to 1996.

The subjects consisted of 55 men and 55 women 40 to 80 years old.

Histologically, the 107 benign tumors comprised 37 ameloblastomas, 36 compound odontomas, 20 complex odontomas, 4 calcifying odontogenic cysts, 3 odontogenic fibromas, 3 odontogenic myxomas, 2 ameloblastic fibro-odontomas, 1 adenomatoid odontogenic tumor, and 1 benign cementoblastoma. The 3 malignant tumors consisted of 2 primary intraosseous carcinomas and 1 malignant ameloblastoma.

Most of the ameloblastomas occurred in the posterior portion of mandible, and many odontomas occurred in the incisor region of both the maxilla and the mandible.

All tumors were treated surgically, and various of procedures were used.

All three odontogenic carcinomas spread extensively throughout the mandible. There has been no evidence of disease in one patient, one patient died of the oral carcinoma, and the other patient died of lung metastasis.
\end{abstract}

Key words: odontogenic tumors (歯原性腫瘍), WHO classification (WHO 分類), clinicostatistical evaluations（臨床統計的検討）

\section{緒言}

歯原性腫瘍は歯を形成する組織に由来する腫瘍で, 大部 分は顎骨中心性に発生し緩慢に発育する．また，無症状に 経過するため臨床的に正確な数を把握することが難しく, その臨床統計的報告は少ない. 今回, 当科開設後 23 年間に 経験した歯原性腫湯110例について，1992年 WHO 組織学 的分類 ${ }^{1)}$ に準じ, 臨床統計的検討を行ったので報告する.

\section{対象および方法}

対象は1973年12月当科開設以来, 1996年11月末までの 23

新潟大学歯学部口腔外科学第二講座

(主任 : 高木律男教授)

Second Department of Oral and Maxillofacial Surgery, Faculty of Dentistry, Niigata University (Chief: Prof. Ritsuo Takagi)

受付日：平成 12 年 8 月 11 日
年間に新潟大学歯学部附属病院第 2 口腔外科を受診した 26,868 名の内, 主に手術摘出材料から WHO 分類 (1992年) に準じ, 歯原性腫瘍と確定診断された 110 例（0.4\%）であ る.これらについて, 性別, 年齢, 主訴, 部位, 治療法を調 查, 検討した.

\section{結果}

\section{1. 組織型別症例数 (表 1 )}

110例のうち良性腫瘍は107例（97.3\%）であり，悪性腫 瘍は 3 例 $(2.7 \%)$ であった。

良性腫瘍ではエナメル上皮腫が 37 例 $(33.7 \%)$ と最も多 く, 次に集合性歯牙腫36例 $(32.8 \%)$, 複雑性歯牙腫 20 例 (18.2\%) で, この 3 者で全例の $84.7 \%$ を占めていた. その 他は, 石灰化歯原性囊胞 ( 4 例), 歯原性粘液腫 ( 3 例), 歯 原性線維腫（3 例), エナメル上皮線維歯牙腫（2 例）, 腺様 
表 1 組織型別症例数と性別 - 年齢

\begin{tabular}{|c|c|c|c|c|}
\hline & 症 例 数 & 男 & 女 & 年 㱓 (平均) \\
\hline $\begin{array}{l}\text { 良性 } \\
\text { エナメル上皮腫 } \\
\text { 集合性歯牙腫 } \\
\text { 複雑性歯牙腫 } \\
\text { 石灰化歯原性囊胞 } \\
\text { 歯原性線維腫 } \\
\text { 歯原性粘液腫 } \\
\text { エナメル上皮線維歯牙腫 } \\
\text { 腺様歯原性腫瘍 } \\
\text { 良性セメント芽細胞腫 }\end{array}$ & $\begin{aligned} 37 & (33.7 \%) \\
36 & (32.8 \%) \\
20 & (18.2 \%) \\
4 & (3.6 \%) \\
3 & (2.7 \%) \\
3 & (2.7 \%) \\
2 & (1.8 \%) \\
1 & (0.9 \%) \\
1 & (0.9 \%)\end{aligned}$ & $\begin{array}{r}24 \\
16 \\
8 \\
2 \\
2 \\
2 \\
0 \\
0 \\
0\end{array}$ & $\begin{array}{r}13 \\
20 \\
12 \\
2 \\
1 \\
1 \\
2 \\
1 \\
1\end{array}$ & $\begin{array}{rr}12 \sim 77 & (37.0) \\
6 \sim 77 & (23.5) \\
4 \sim 52 & (18.8) \\
15 \sim 41 & (29.5) \\
20 \sim 61 & (37.7) \\
48 \sim 63 & (55.0) \\
7 \sim 22 & (14.5) \\
21 & \\
15 & \end{array}$ \\
\hline 小 計 & $107(97.3 \%)$ & 54 & 53 & \\
\hline $\begin{array}{l}\text { 悪性 } \\
\text { 原発性骨内癌 } \\
\text { 悪性エナメル上皮腫 }\end{array}$ & $\begin{array}{l}2(1.8 \%) \\
1(0.9 \%)\end{array}$ & $\begin{array}{l}0 \\
1\end{array}$ & $\begin{array}{l}2 \\
0\end{array}$ & $\begin{array}{l}23 \sim 80(51.5) \\
67\end{array}$ \\
\hline 小 & $3(2.7 \%)$ & 1 & 2 & \\
\hline 合 & $110(100 \%)$ & 55 & 55 & \\
\hline
\end{tabular}

表 2 主訴別症例数

\begin{tabular}{|c|c|c|c|c|c|c|}
\hline & 膨隆 & $\mathrm{X}-\mathrm{P}$ で指摘 & 疼痛 & 萌出異常 & 違和感 & その 他 \\
\hline \multicolumn{7}{|l|}{ 良性 } \\
\hline エナメル上皮腫 & 29 & 0 & 4 & 0 & 1 & 抜歯窩治癒不全, 開口障害, 排膿 各 1 \\
\hline 集合性歯牙腫 & 3 & 20 & 7 & 6 & 0 & \\
\hline 複雑性歯牙腫 & 2 & 9 & 3 & 5 & 0 & 食片压入 1 \\
\hline 石灰化歯原性囊胞 & 4 & 0 & 0 & 0 & 0 & \\
\hline 歯原性線維腫 & 0 & 0 & 1 & 0 & 1 & 歯の動摇 1 \\
\hline 歯原性粘液腫 & 3 & 0 & 0 & 0 & 0 & \\
\hline エナメル上皮線維歯牙腫 & 1 & 0 & 0 & 1 & 0 & \\
\hline 腺様歯原性腫瘍 & 0 & 0 & 0 & 1 & 0 & \\
\hline 良性セメント芽細胞腫 & 1 & 0 & 0 & 0 & 0 & \\
\hline 小 計 & 43 & 29 & 15 & 13 & 2 & \\
\hline \multicolumn{7}{|l|}{ 悪性 } \\
\hline 原発性骨内癌 & 2 & 0 & 0 & 0 & 0 & \\
\hline 悪性エナメル上皮腫 & 1 & 0 & 0 & 0 & 0 & \\
\hline 小 & 3 & 0 & 0 & 0 & 0 & \\
\hline 合計 & 46 & 29 & 15 & 13 & 2 & \\
\hline
\end{tabular}

歯原性腫瘍 ( 1 例), 良性セメント芽細胞腫（１例）であっ た.一方, 悪性腫瘍では原発性骨内癌が 2 例, 悪性エナメル 上皮腫が 1 例であった。

\section{2 . 性別について（表 1 )}

歯原性腫瘍全例では, 男性55例, 女性55例, 男女比は 1 : 1 と差はみられなかった. 症例数の多かったエナメル上皮 腫は男性に多く，歯牙腫は女性に多くみられた。

\section{3. 年齢について (表 1 )}

エナメル上皮腫の初診時年齢は最低12歳, 最高77歳で平 均37.0歳であった。

集合性歯牙腫, 複雑性柬牙腫をまとめると初診時年齢は, 最低 4 歳, 最高77歳で平均 20.3 歳であった。とに が最も多く, 20歳未満は37例 $(66.1 \%)$ であった.

\section{4. 主訴について (表 2 )}

エナメル上皮腫は 29 例 $(78.4 \%)$ が顎骨の膨隆を主訴と 
表 3 部位別症例数

\begin{tabular}{|c|c|c|c|c|c|c|c|c|c|}
\hline & \multicolumn{4}{|c|}{ 上. } & \multicolumn{5}{|c|}{ 下 } \\
\hline & 前苗部 & $\begin{array}{l}\text { 前歯部 } \\
\text { 臼歯部 }\end{array}$ & 兒歯部 & 小 計 & 前歯部 & $\begin{array}{l}\text { 前歯部 } \\
\text { 臼歯部 }\end{array}$ & 臼歯部 & $\begin{array}{l}\text { 臼歯部 } \\
\text { 下顎枝 }\end{array}$ & 小 計 \\
\hline \multicolumn{10}{|l|}{ 良性 } \\
\hline エナメル :波腫 & 0 & 2 & 0 & $2(5.4 \%)$ & 0 & 11 & 2 & $21(1)$ & $35(94.6 \%)$ \\
\hline 集合性断少'腫 & 13 & 1 & 0 & $14(38.9 \%)$ & 14 & 7 & 1 & 0 & $22(61.1 \%)$ \\
\hline 複雑性菌少腰 & 7 & 1 & 4 & $12(60.0 \%)$ & 3 & 1 & 4 & 0 & $8(40.0 \%)$ \\
\hline 石灰化歯原性:萑胞 & 1 & 0 & 0 & $1(25.0 \%)$ & 0 & 3 & 0 & 0 & $3(75.0 \%)$ \\
\hline 柬原性線維腫 & 0 & 0 & 0 & 0 & 1 & 0 & 2 & 0 & $3(100 \%)$ \\
\hline 茵原性粘液腫 & 0 & 0 & 0 & 0 & 0 & 1 & 1 & 1 & $3(100 \%)$ \\
\hline エナメル上皮線維秚少腫 & 0 & 0 & 1 & $1(50.0 \%)$ & 0 & 0 & 1 & 0 & $1(50.0 \%)$ \\
\hline 腺様歯原性腫瘍 & 0 & 0 & 0 & 0 & 0 & 0 & 1 & 0 & $1(100 \%)$ \\
\hline 良性セメント芽細胞腫 & 0 & 0 & 0 & 0 & 0 & 0 & 1 & 0 & $1(100 \%)$ \\
\hline 小 計 & 21 & 4 & 5 & 30 & 18 & 23 & 13 & $22(1)$ & 77 \\
\hline \multicolumn{10}{|l|}{ 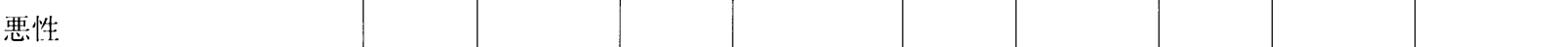 } \\
\hline 原発性䧎内澏 & 0 & 0 & 0 & 0 & 0 & 1 & 1 & 0 & $2(100 \%)$ \\
\hline 悪性エナメルト皮腫 & 0 & 0 & 0 & 0 & 0 & 0 & 0 & 1 & $1(100 \%)$ \\
\hline 小 & 0 & 0 & 0 & 0 & 0 & 1 & 1 & 1 & 3 \\
\hline 合 & 21 & 4 & 5 & $30(27.3 \%)$ & 18 & 24 & 14 & $23(1)$ & $80(72.7 \%)$ \\
\hline
\end{tabular}

しており，㐘牙腫では X 線撮影により発見された症例が 29 例 $(51.8 \%)$ と多く，その他は疼痛などであった.

\section{5 . 部位別症例数 (表 3 )}

歯原性腫瘍全例での発生部位は下顎が80例 $(72.7 \%)$, 上 顎が30例 $(27.3 \%)$ で，とくに下顎臼㐘部を中心に発生す るものが多かった。エナメル上皮腫では37例中 35 例 (94.6\%) が下顎に発生し，このうち臼歯部から下顎枝を中 心に発生した症例が22例（62.9\%）を占めていた．歯牙腫 では上顎26例 $(46.4 \%)$ ，下顎30例 $(53.6 \%)$ と差はみられ なかったが，上下顎とも前歯部に多かった，上顎26例中 20 例 $(76.9 \%)$ ，下顎30例中 17 例 $(56.7 \%)$ が前歯部に発生し ていた。また，悪性の 3 例については，いずれも下顎臼歯部 に関連していた。

\section{6 . 治療法について}

良性腫瘍では摘出が大多数 82 例 $(77.4 \%)$ を占めていた が, 腫瘍の種類・大きさにより摘出後に骨の削除を加えた 症例が, エナメル上皮腫で 4 例, 歯原性線維腫, 歯原性粘液 腫の各全 3 例にみられた。 また，臨床的に準悪性とされる エナメル上皮腫では，区域切除12例，部分切除11例と多岐 に及んでいた。悪性の 3 例は区域切除，関節離断のみで あった。

\section{考察}

歯原性腫瘍の疾患数については, 腫瘍自体が良性病変で あることが多く，正確な数值が把握しにくい2）といわれて いる。当科は人口約 50 万人に歯学部付属病院が 2 施設，口 腔外科学 4 講座あるうちの 1 講座で 23 年間で 110 例の報告 であるが, Regezi らは41年間で706例の報告をしている3） 今回の WHO 分類の改訂で, これまでいわゆるセメント質 腫として分類されていた疾患のうち, 良性セメント芽細胞 腫のみが真の歯原性腫瘍として分類に残されたことによ り，セメント質腫の報告が激減した。当科でも，同期間に旧 分類でのセメント質腫を12例経験したが, 病理組織学的に 良性セメント芽細胞腫と診断された症例は 1 例（0.9\%）で あった.今回の報告では, エナメル上皮腫, 集合性歯牙腫, 複雑性歯牙腫で全体の $84.7 \%$ を占めている。この点に関し て，これまでは，エナメル上皮腫が大部分を占め，次いで歯 牙腫とセメント質腫が多いとする報告 2,4 ) と, 歯牙腫が半 数を越え, エナメル上皮腫, セメント質腫の順に多いとす る報告 $\left.{ }^{3}, 5\right)$ がみられたが，セメント質腫が新たに分類され たことにより，本報告と同様にエナメル上皮腫と歯牙腫 （集合性，複雑性）で歯原性腫瘍の大半を占めるとする報告 が多くなると思われる。

また, 新たに歯原性腫瘍に加えられた歯原性扁平上皮腫, 歯原性明細胞腫および歯原性癌肉腫は当科では経験しな 
かった。

歯牙腫56例では集合性歯牙腫 $(36 / 56 ; 64.3 \%)$ が複雑 性歯牙腫 $(20 / 56 ; 35.7 \%)$ より多く, 諸家の報告にほぼ

一致している ${ }^{3,5 \sim 7)}$.

性別においては, 男女比は歯原性腫瘍全体でみると $1: 1$ で性差はみられなかった.この点に関して，1992年以前の 報告では女性がやや多い5) とされているが, セメント質腫 が女性に多いことが影響したと考えられる。組織別では， エナメル上皮腫は男性にやや多く，また，歯牙腫は女性に 多いという点で, 諸家の報告 $2,4 \sim 7)$ と一致していた.

年齢では, エナメル上皮腫は 10 歳台, 20 歳台にピークが あるが, 各年代層に広くみられ，平均年齢37.0歳という結 果は, 諸家の報告とほぼ一致する ${ }^{4 \sim 6)}$. 歯牙腫は集合性歯 牙腫も複雑性歯牙腫もともに諸家の報告 $3,5 ７$ ) と同様, 10歳台が約半数を占め, 平均年齢はおのおの 23.5 歳, 18.8 歳 で, 混合歯列期から永久歯の萌出が終了する時期に集中し ており，この時期に萌出異常で X 線で発見されることが多 いためと思われる.

部位別症例数ではエナメル上皮腫は既報告と同様 $1,2,4 ７$ ) 下顎に圧倒的に多く，上顎にはまれで，下顎でも兒歯部か ら下顎枝にかけてが好発部位である，一方，歯牙腫につい ては, 本研究では上下顎の前㐘部に約 8 割が発生していた. この点に関しては, 集合性歯牙腫は上顎に, 複雑性歯牙腫 は下顎に多く発生する報告 $\left.{ }^{2}, 5\right)$ と, 上下差はないという報 告 3,6 ) がある，その他, 歯原性線維腫, 歯原性粘液腫はす べて下顎に発生し，とくに臼歯部を中心としていた。この 点は上顎にも約半数が発生した報告 3,5$)$ もる.

治療法については，良性腫瘍は摘出が原則であるが，と くにエナメル上皮腫では局所浸潤の性格が強く, 再発しや すいため, 大きさ, 部位により摘出から顎骨切除まで種々 の治療法が選択されており, 若年者の unicystic amelo- blastoma に開空療法が奏効した症例もみられた。エナメ ル上皮腫において再発例は37例中 1 例 $(2.7 \%)$ であった。 一方, 悪性腫瘍では原発性骨内癌 2 例で, 無病生存, 原病死 が各 1 例, 悪性エナメル上皮腫は肺転移死の転帰をとった.

\section{結語}

当科開設後 23 年間に経験した歯原性腫瘍 110 例について， WHO の新分類（1992年）に基づいて臨床統計的に検討し たので報告した。

稿を終えるに臨み, 本研究にご懇篤なる御指導を賜わりま した, 新潟大学名誉教授大橋 靖先生, ならびに附属病院臨床 検査室主任鈴木 誠先生に深謝いたします。

本研究の要旨は13th International Conference on Oral and Maxillofacial Surgery（1997年10月20-24日，京都）に おいて発表した。

\section{引用 文 献}

1) Kramer, I.R.H., Pindborg, J.J., et al.: Histological typing of odontogenic tumours. 2 nd Ed, Berlin Springer-Veriag, 1992, P11-27.

2）石川梧朗：歯原性腫瘍について. 口病誌 49: 555-567 1982.

3) Regezi, J.A., Kerr, D.A., et al.: Odontogenic tumors: analysis of 706 cases. J Oral Surg 36: 771-778 1978.

4）国芳秀晴, 吉田雅司, 他：当科における過去 10 年間 （1976年～1985年）良性腫湟の臨床統計的観察.日口 外誌 35: 700-712 1989 .

5）樋口勝規, 田代英雄, 他 : 歯原性腫瘍の臨床的検討。 日口外誌 36: 1699-1707 1990.

6）今村英夫, 稲井哲郎, 他：歯原性腫演56例の臨床統 計学的分析. 口腔腫場 9: 276-281 1997.

7）鶴巻 浩, 大橋 靖：歯牙腫の臨床統計。歯科 ジャーナル 37: 766-770 1993. 